\title{
'Chlorobium-type' Vesicles of Photosynthetically-grown Chloroflexus aurantiacus Observed Using Negative Staining Techniques
}

\author{
By MICHAEL T. MADIGAN* AND THOMAS D. BROCK \\ Department of Bacteriology, University of Wisconsin, Madison, Wisconsin 53706, U.S.A.
}

(Received 4 April 1977)

\begin{abstract}
Electron microscopic studies of several strains of Chloroflexus aurantiacus, a new genus of filamentous photosynthetic bacteria containing bacteriochlorophylls $a$ and $c$, demonstrated that all strains contained vesicular structures very similar to the 'chlorobium vesicles' of the green bacteria when grown under anaerobic conditions in the light. The dimensions of these structures varied from strain to strain; they were 90 to $150 \mathrm{~nm}$ long and 25 to $70 \mathrm{~nm}$ wide. Photoautotrophically-grown $C$. aurantiacus as well as photoheterotrophically-grown organisms contained photosynthetic vesicles, while heterotrophically, dark-grown organisms contained no bacteriochlorophyll and no distinguishable 'chlorobium vesicles'. Filament diameter and length varied from strain to strain, although all strains examined were regularly septate.
\end{abstract}

\section{INTRODUCTION}

Chloroflexus aurantiacus has recently been described by Pierson \& Castenholz (1974a,b) as a member of a new genus of bacteriochlorophyll $c$ - and $a$-containing photosynthetic bacteria. The organism is filamentous, and inhabits alkaline hot spring effluents at temperatures from 50 to $70^{\circ} \mathrm{C}$ (Pierson \& Castenholz, 197I; Bauld \& Brock, 1973; Doemel \& Brock, 1974). Chloroflexus aurantiacus resembles the green and purple sulphur bacteria in that it is capable of photoautotrophic growth with sulphide (Madigan \& Brock, 1975), and shows links with the Rhodospirillaceae by its ability to grow photoheterotrophically with or without sulphide, and heterotrophically in the dark (Pierson \& Castenholz, 1974a; Madigan, Petersen \& Brock, 1974). Chloroflexus aurantiacus also possesses characteristics which relate it to the blue-green algae (cyanobacteria) in that it is a gliding, filamentous organism and contains $\beta$-carotene (Halfen, Pierson \& Francis, 1972).

The bacteriochlorophyll content of $C$. aurantiacus together with its deoxyribonucleic acid base ratio of 53 to $55 \%$ (as mol \% GC) clearly indicate the strong links between this organism and the members of the green sulphur bacteria. In light of this it was interesting to note that Pierson \& Castenholz ( $1974 a$ ) found vesicular structures in photosyntheticallygrown $C$. aurantiacus very similar to the 'chlorobium vesicles' first described for green bacteria by Cohen-Bazire, Pfennig \& Kunisawa (1964). The vesicles in C. aurantiacus lay at the periphery of the cell and appeared to be closely appressed to the cytoplasmic membrane, with their long axes oriented along the long axis of the filament (Pierson \& Castenholz, I974a).

Since the isolation and characterization of the type strain of Chloroflexus aurantiacus (strain J-IO-fl; Pierson \& Castenholz, 197I ; 1974 $a, b$ ) several new strains have been isolated from a variety of alkaline hot springs in Yellowstone National Park (Bauld, I973). These strains have been nutritionally characterized (Madigan et al., 1974), and ecological studies

* Present address: Department of Microbiology, Indiana University, Bloomington, Indiana 4740I, U.S.A. 
on the natural populations from which the strains were derived have been undertaken (Bauld, I973; Bauld \& Brock, I973). Pierson \& Castenholz (1974a) examined thin-sectioned preparations for the presence of 'chlorobium vesicles'. Negative staining provides a simpler and more clear cut way of showing these vesicular structures (Holt, Conti \& Fuller, I966) and we used this technique in our study of the Yellowstone isolates. We also examined the effect of growth conditions on the formation of vesicles, making use of cultures which we succeeded in adapting to photoautotrophic conditions (Madigan \& Brock, 1975).

\section{METHODS}

Organisms. The cultures of the type strain (J-10-fl) and strain oK-70-fl were provided by R. W. Castenholz; they derive from Japanese and Oregon hot springs, respectively (Pierson \& Castenholz, 1974a). Strain Y-400-fl was isolated by Castenholz from material provided by John Bauld (Department of Microbiology, University of Melbourne, Australia) which was taken from a thick mat at Octopus Spring (formerly referred to as Pool A), an alkaline hot spring located about $0.15 \mathrm{~km} \mathrm{SSE}$ of Great Fountain Geyser, Yellowstone National Park, U.S.A. Strain 396-I was isolated by Bauld from Conophyton Pool (unofficial name), a spring located in the south end of Fairy Creek Meadow, Lower Geyser Basin, Yellowstone National Park (Walter, Bauld \& Brock, 1972). Strain 254-2 was isolated by Bauld \& Brock (1973) from a thin mat in the outflow of Grassland Spring, Lower Geyser Basin. Methanol extracts of all the Yellowstone isolates showed absorption spectra typical of bacteriochlorophylls $a$ and $c$. A main peak in the red region at $668 \mathrm{~nm}$ is characteristic of bacteriochlorophyll $c$ (Stanier \& Smith, 1960), and a smaller peak at $770 \mathrm{~nm}$ is due to bacteriochlorophyll $a$.

Cultivation. Cultures of all strains of $C$. aurantiacus were grown photosynthetically under anaerobic conditions as described by Madigan et al. (1974). Modified medium D at pH 8.0 was used as a basal medium, and this was supplemented with $\mathrm{CO}_{2}$ and sulphide for photoautotrophic growth. For photoheterotrophic growth, single organic carbon sources or yeast extract were used, at concentrations from 0.01 to $0.2 \%(w / v)$. Sulphide was added to all media at a final concentration of $2 \mathrm{mM}$. Heterotrophic growth occurred in rapidly stirred 250 or $500 \mathrm{ml}$ culture flasks containing 25 or $50 \mathrm{ml}$ of the complex medium described by Pierson \& Castenholz (1974a) without sulphide, and capped with metal closures. All incubations were at $50{ }^{\circ} \mathrm{C}$ at a light intensity of 0.5 to I klx from a tungsten source.

Electron microscopy. Copper grids 200 mesh, covered with a film of $2.5 \%$ (w/v) parloidion (in amyl acetate) strengthened by the addition of a thin film of evaporated carbon, were used in all studies. Negative staining was done according to Remsen, Valois \& Watson (1967) except that $1.5 \%$ (w/v) phosphotungstic acid pH 6.8 was used. Most cell suspensions were briefly homogenized with a Teflon homogenizer before being placed on the grids to break up any clumps. This procedure also disrupted some of the filaments, allowing stain to penetrate and enhance contrast.

For chemical fixation, cells were prefixed for $\mathrm{I} h$ at room temperature in $\mathrm{I} \%(\mathrm{v} / \mathrm{v})$ glutaraldehyde in $0.05 \mathrm{M}$-potassium phosphate $\mathrm{pH} 7.0$, and postfixed for $\mathrm{I}$ h in $\mathrm{I} \%(\mathrm{w} / \mathrm{v}) \mathrm{OsO}_{4}$ in phosphate buffer. Cells were washed, suspended in $2.5 \%(\mathrm{w} / \mathrm{v})$ ion agar, dehydrated in an acetone series and embedded in Durcupan (Fluka, 9470 Buchs, Switzerland). Sections were cut on a Porter-Blum ultramicrotome using glass knives, and double stained with $1 \cdot 5 \%(\mathrm{w} / \mathrm{v})$ uranyl acetate followed by lead citrate (Reynolds, 1963).

All electron microscopy was done on a Zeiss EM-9S operating at $60 \mathrm{kV}$.

Photomicroscopy. Photomicrographs were taken on a Zeiss Universal phase-contrast microscope fitted with a Topcon $35 \mathrm{~mm}$ single-lens reflex camera. Kodak Plus X (ASA 125) or Tri-X (ASA 400) black-and-white films were used for all photomicrographs.

\section{RESULTS AND DISCUSSION}

\section{Photomicroscopy}

A photomicrograph of one of the Yellowstone strains is shown in Fig. I. Morphologically, the Yellowstone strains appear similar to the type strain of $C$. aurantiacus, $\mathrm{J}$-10-fl (Pierson \& Castenholz, 1974a). Filament lengths vary considerably, ranging from 30 to $300 \mu \mathrm{m}$. Filament widths vary slightly from strain to strain, and also, to some extent, with growth conditions. Strains 254-2 and J-IO-fl have average diameters of 0.5 to $0.6 \mu \mathrm{m}$, whereas strains Y-400-fl, 396-I and OK-70-fl are wider (average diameters 0.7 to $0.8 \mu \mathrm{m}$ ). 


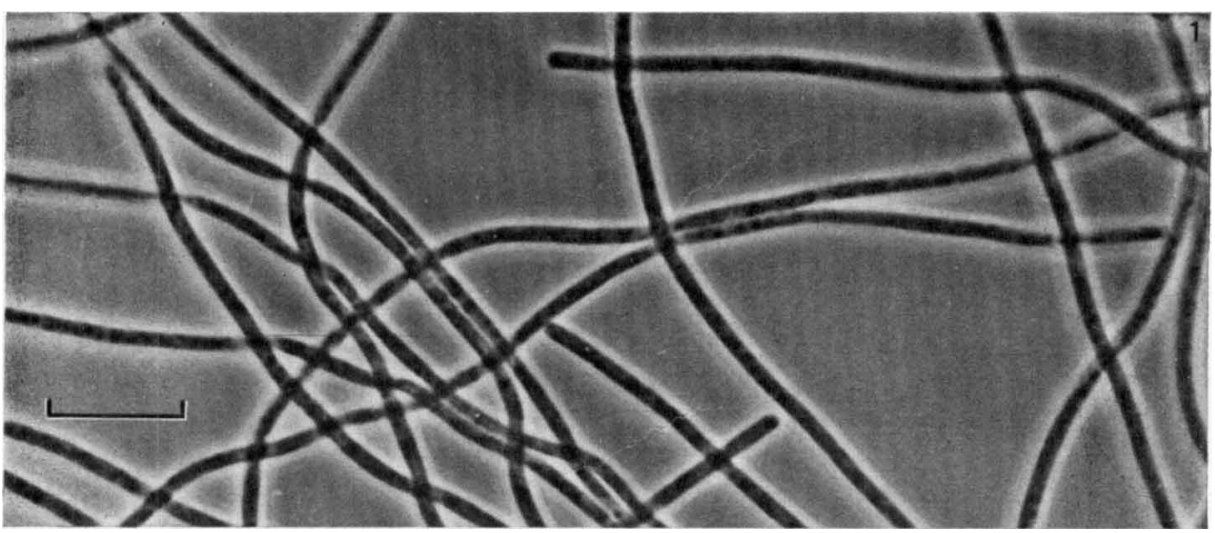

Fig. I. Photomicrograph of Chloroflexus aurantiacus strain 396-1. Bar marker represents $10 \mu \mathrm{m}$.
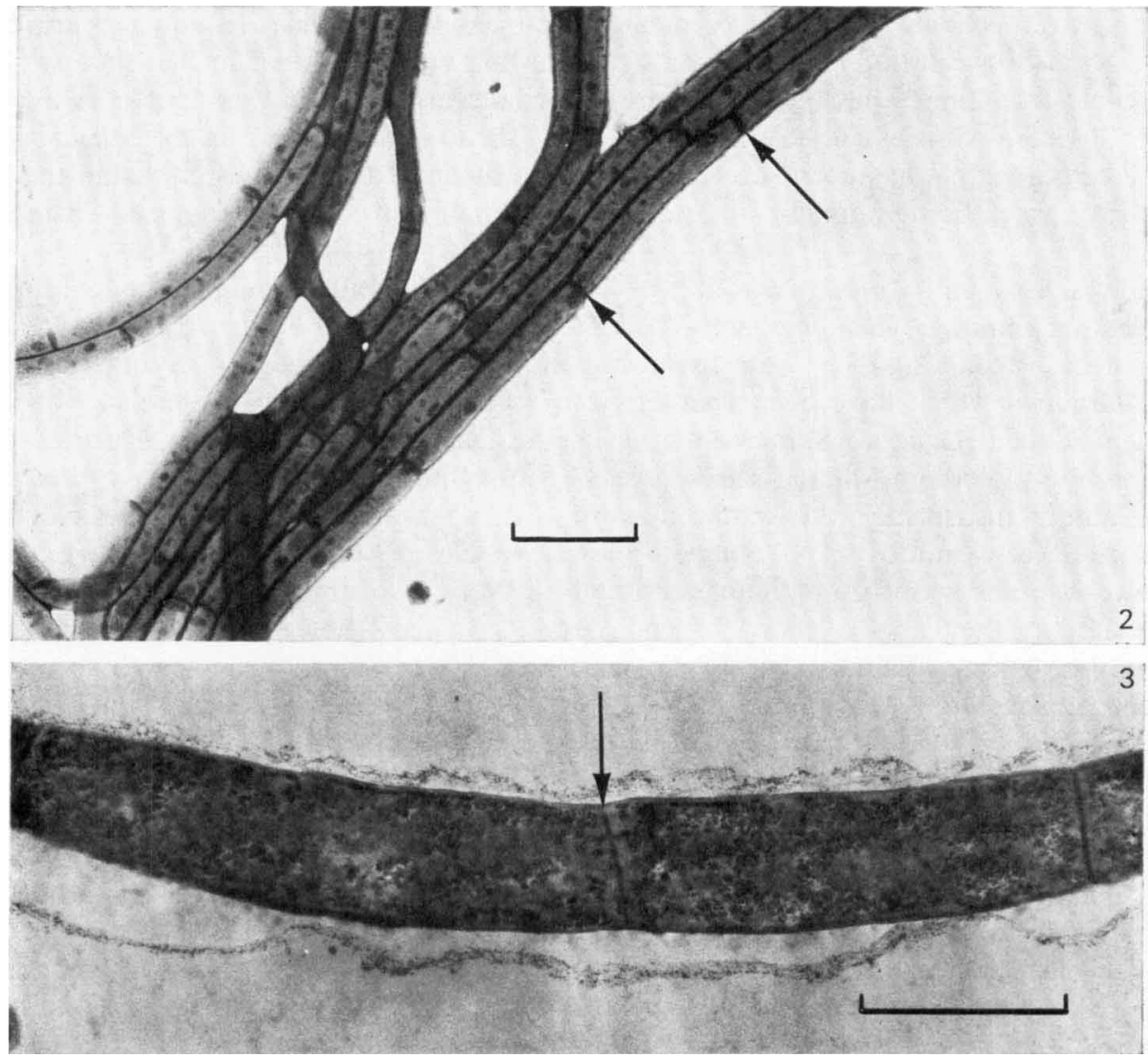

Fig. 2. Low magnification electron micrograph of negatively stained filaments of Chloroflexus aurantiacus strain 254-2. Bar marker represents $2 \mu \mathrm{m}$.

Fig. 3. Thin section of $C$. aurantiacus strain oK-70-fl. Bar marker represents $0.5 \mu \mathrm{m}$.

Note septa (arrows) in both figures, and prominent mesosomes in Fig. 2. 


\section{Electron microscopy}

Although not evident in photomicrographs, filaments of all strains of $C$. aurantiacus examined with the electron microscope are regularly septate, with cell lengths from $I \cdot 5$ to $6 \mu \mathrm{m}$. Figure 2 clearly demonstrates the septa in negatively stained whole cells, and Fig. 3 shows septa as seen in thin sections. Several densely stained inclusions, probably mesosomal elements, are also visible in Fig. 2. Mesosomes were detected in several of the strains of C. aurantiacus examined by Pierson \& Castenholz (1974a), and they are known to be a prominent feature of the green bacteria (Cohen-Bazire et al., 1964). A wavy granular substance can be seen in Fig. 3 which probably represents the remnants of a sheath. Pierson \& Castenholz (1974a) noted that filaments of strains oK-70-fl and J-IO-fl appeared to be sheathed and, although we have not obtained conclusive evidence using the electron microscope, phase-contrast microscopy has occasionally allowed observations of a sheath when an individual cell lyses leaving a clear area connecting intact cells along the filament.

The vesicles of photosynthetically-grown $C$. aurantiacus are most clearly observed in negatively stained preparations. Figures 4,5 and 6 show filaments of strains oK-70-fl, 396-I and 254-2 respectively; the cells were gently homogenized to break the filaments and allow penetration of the stain. The vesicular structures are clearly evident in these preparations as non-electron-dense ellipsoidal structures distributed throughout the interior of the cells. In Fig. 4 several vesicles can be seen aligned along the longitudinal axis in the cortical region of the cell, and this has been shown to be the location of the vesicles in chemically fixed preparations of $C$. aurantiacus not subjected to homogenization (Pierson \& Castenholz, 1974a).

The vesicles from $C$. aurantiacus appear morphologically quite similar to the "chlorobium vesicles' of Chloropseudomonas ethylica (Chlorobium sp., Gray et al., 1973), first studied using negative staining techniques by Holt et al. (1966), and to the photosynthetic vesicles of Chlorobium which have been characterized in detail by Cruden \& Stanier (1970) and Cruden, Cohen-Bazire \& Stanier (1970). The vesicles of strain oK-70-fl measure 100 to I $50 \mathrm{~nm}$ by 45 to $70 \mathrm{~nm}$, whereas the vesicles of strain 396-I are of a similar length but somewhat thinner, measuring 35 to $50 \mathrm{~nm}$ in width. Strain 254-2 possesses smaller vesicles which measure 90 to $95 \mathrm{~nm}$ by 25 to $35 \mathrm{~nm}$, while the vesicles of strain Y-400-fl (Fig. 9) measure 100 to $150 \mathrm{~nm}$ by 40 to $60 \mathrm{~nm}$. Thus, although the vesicles of these strains are morphologically similar, they appear to be of considerably different average size, with a general correlation between filament width and vesicle dimensions in agreement with the data of Pierson \& Castenholz (1974a).

Figure 7 shows a group of vesicles which have been released by the homogenization process and remain associated with cell membrane material. It is apparent that the vesicles from any one pure culture are heterogeneous in morphology, varying slightly in physical dimensions yet still retaining the typical ellipsoidal shape characteristic of these structures as originally described for Chlorobium (Cohen-Bazire et al., 1964). Although not demonstrable by negative staining techniques, Pierson \& Castenholz (1974a) have determined from thin-sectioned material that the vesicles in Chloroflexus, as in Chlorobium, are bound by a $2 \mathrm{~nm}$ thick single-layered (non-unit) membrane. Since the vesicles from the strains examined in the present work retain their structural integrity upon release from the cell, it is likely that they possess an outer layer of a similar nature.

Pierson \& Castenholz (1974b) have shown that bacteriochlorophyll synthesis in Chloroflexus is repressed under aerobic conditions. We have examined heterotrophically, darkgrown $C$. aurantiacus for the presence of photosynthetic vesicles and have found that cells grown under highly aerated conditions (see Methods) do not possess photosynthetic vesicles. In addition, anaerobic, photoautotrophically-grown cells of strain oK-70-fl contain a vesicular photosynthetic apparatus indistinguishable from cells grown anaerobically under photoheterotrophic conditions. 

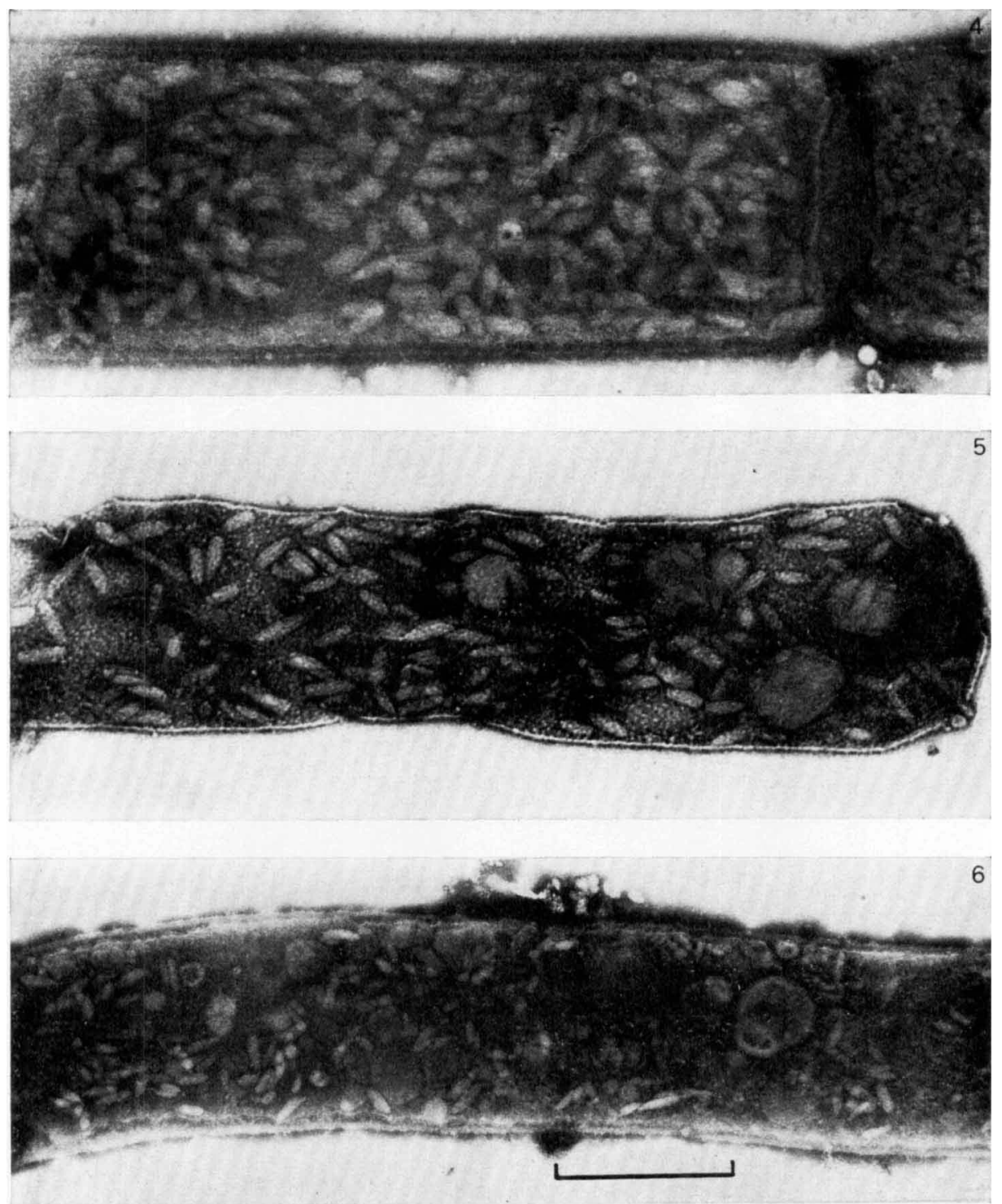

Figs 4, 5 and 6. Electron micrographs (at the same magnification) of negatively stained homogenized filaments of Chloroflexus aurantiacus: Fig. 4, strain oK-70-fl; Fig. 5, strain 396-1; Fig. 6, strain 254-2. Note photosynthetic vesicles distributed throughout the cells. Bar marker represents $0.5 \mu \mathrm{m}$.

\section{General discussion}

As has been pointed out by Trüper (1976), the isolation and characterization of $C$. aurantiacus has posed some taxonomic problems, in that this organism shares affinities with several different prokaryotic groups including the blue-green algae, the achlorophyllous flexibacteria, and the phototrophic bacteria.

Despite its widespread affinities. Chloroflexus is clearly a photosynthetic bacterium, in that its photosynthesis is of the anoxygenic type mediated by bacteriochlorophylls (Pierson \& Castenholz, I971, I974a, $b$; Madigan \& Brock, 1975). This characteristic distinguishes Chloroflexus from the chlorophyll $a$-containing blue-green algae (cyanobacteria). The bacteriochlorophylls of $C$. aurantiacus are bacteriochlorophylls $a$ and $c$, a complement of bacteriochlorophylls unique to members of the Chlorobiaceae (Pfennig, I967). Although 

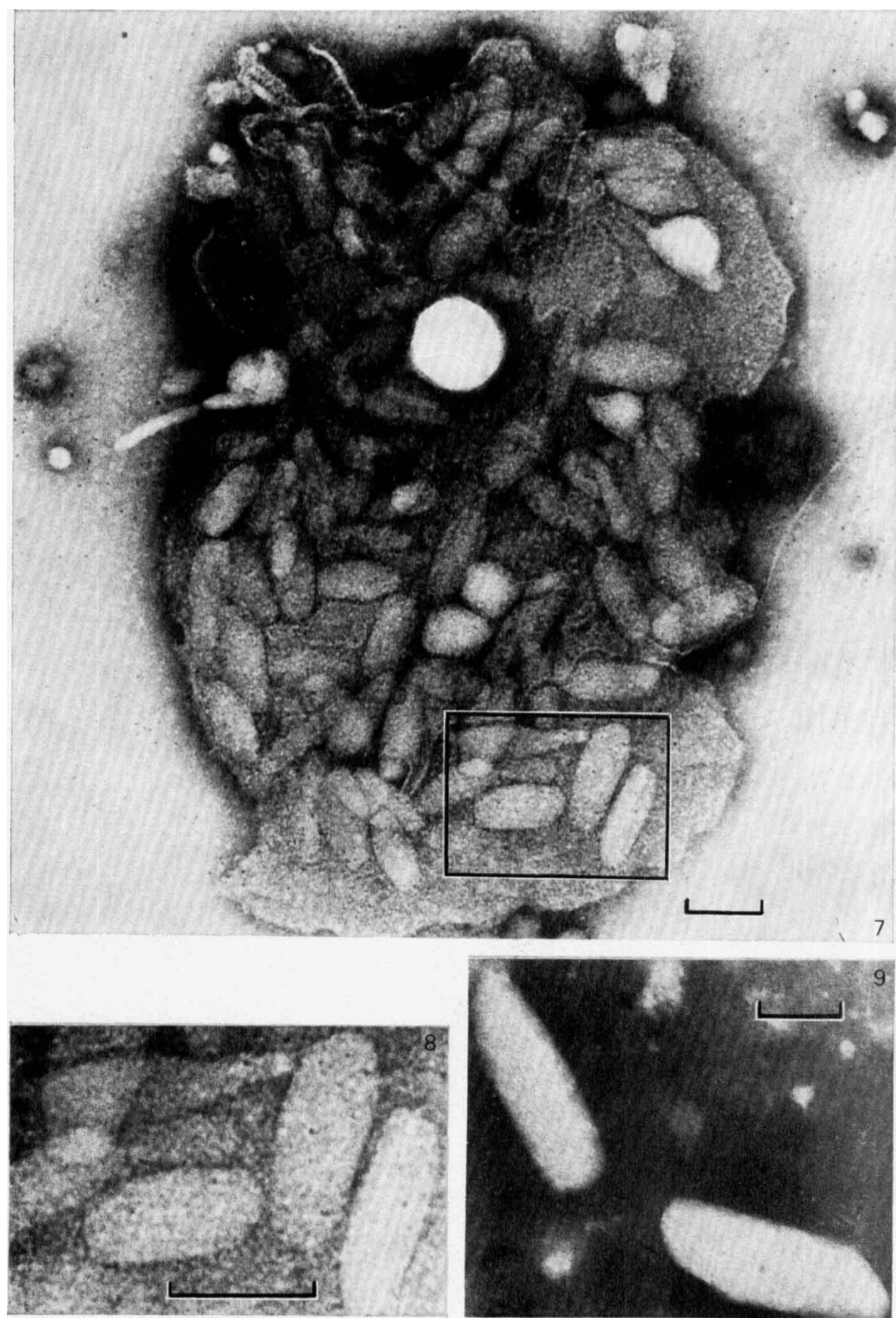

Figs 7 and 8. Electron micrographs of vesicles (negatively stained) released from Chloroflexus aurantiacus strain oK-70-fl after homogenization. Figure 8 is an enlargement of the marked area in Fig. 7. Bar markers represent $0.1 \mu \mathrm{m}$.

Fig. 9. Vesicles released from $C$. aurantiacus strain Y-400-fl. Bar marker represents $50 \mathrm{~nm}$. 
Pierson \& Castenholz (1974a) did not provide evidence that the vesicular structure of photosynthetically-grown Chloroflexus actually contained the bacteriochlorophylls, it is likely that at least bacteriochlorophyll $c$ is localized in this structure as is the case in Chlorobium (Cruden \& Stanier, 1970).

Thus, although filamentous in morphology and capable of aerobic respiratory growth, Chloroflexus aurantiacus responds to anaerobic, light conditions by synthesizing bacteriochlorophylls $a$ and $c$ (Pierson \& Castenholz, 1974b), and a vesicular structure very similar to the photosynthetic apparatus of Chlorobium. Due to its unique characteristics it is possible that Chloroflexus represents a transitional type of organism, intermediate in various ways between the photosynthetic bacteria and the oxygenic phototrophs. The blue-green alga (cyanobacterium) Oscillatoria limnetica, which is able to perform anoxygenic photosynthesis using sulphide instead of water as its electron donor (Cohen, Padan \& Shilo, 1975), may represent a similar transitional form. These organisms may prove to be of significance in the development of a phylogenetic scheme leading from the anoxygenic photosynthetic bacteria to the first oxygen-evolving phototrophs.

This work was supported by the College of Agricultural and Life Sciences, University of Wisconsin, the National Science Foundation (GB-35046) and a training grant to M.T.M. from the National Institutes of Health (5-ToI-GM-00686). Discussions with Jack L. Pate provided valuable insight concerning the interpretation of electron micrographs. Special thanks go to Joanne Glaser for her expert instruction in the use of the electron microscope.

\section{REFERENCES}

BAULd, J. (1973). Algal-bacterial interactions in alkaline hot spring effluents. Ph.D. dissertation, University of Wisconsin, U.S.A.

BAuld, J. \& Brock, T. D. (1973). Ecological studies of Chloroflexis, a gliding photosynthetic bacterium. Archiv fiir Mikrobiologie 92, 267-284.

Cohen, Y., Padan, E. \& Shilo, M. (I975). Facultative anoxygenic photosynthesis in the cyanobacterium Oscillatoria limnetica. Journal of Bacteriology' 123, 855-86I.

Cohen-Bazire, G., Pfennig, N. \& Kunisawa, R. (1964). The fine structure of green bacteria. Journal of Cell Biology 22, 207-225.

Cruden, D. L. \& Stanier, R. Y. (I970). The characterization of chlorobium vesicles and membranes isolated from green bacteria. Archiv für Mikrobiologie 72, I15-134.

Cruden, D. L., Cohen-Bazire, G. \& Stanier, R. Y. (1970). Chlorobium vesicles: the photosynthetic organelles of green bacteria. Nature, London 228, $1345^{-1} 347$.

Doemel, W. N. \& Brock, T. D. (1974). Bacterial stromatolites: origin of laminations. Science r84, $1083-1085$.

Gray, B. H., Fowler, C. F., Nugent, N. A., Rigopoulos, N. \& Fuller, R. C. (1973). Reevaluation of Chloropseudomonas ethylica strain 2-K. International Journal of Systematic Bacteriology 23, 256-264.

Halfen, L. N., Pierson, B. K. \& Francis, G. W. (1972). Carotenoids of a gliding organism containing bacteriochlorophylls. Archiv fïr Mikrobiologie 82, 240-246.

Holt, S. C., Conti, S. F. \& Fuller, R. C. (1966). Photosynthetic apparatus in the green bacterium Chloropseudomonas ethylicum. Journal of Bacteriology 91, 31 I-323.

Madigan, M. T. \& Brock, T. D. (1975). Photosynthetic sulfide oxidation by Chloroflexus aurantiacus, a filamentous photosynthetic gliding bacterium. Journal of Bacteriology 122, 782-784.

Madigan, M. T., Petersen, S. R. \& Brock, T. D. (1974). Nutritional studies on Chloroflexus, a filamentous photosynthetic gliding bacterium. Archives of Microbiology 100, 97-103.

Pfennig, N. (1967). Photosynthetic bacteria. Annual Review of Microbiology 21, 285-324.

Pierson, B. K. \& Castenholz, R. W. (1971). Bacteriochlorophylls in gliding filamentous prokaryotes from hot springs. Nature New Biology 233, 25-27.

Pierson, B. K. \& Castenholz, R. W. (I974a). A phototrophic gliding filamentous bacterium of hot springs, Chloroflexus aurantiacus, gen. and sp. nov. Archives of Microbiology 100, 5-24.

Pierson, B. K. \& Castenholz, R. W. (1974b). Studies of pigments and growth in Chloroflexus aurantiacus, a phototrophic filamentous bacterium. Archives of Microbiology roo, 283-305.

Remsen, C. C., Valois, F. W. \& Watson, S. W. (1967). Fine structure of the cytomembranes of Nitrosocystis oceanus. Journal of Bacteriology 94, 422-433.

Reynolds, E. S. (1963). The use of lead citrate at high $\mathrm{pH}$ as an electron opaque stain in electron microscopy. Journal of Cell Biology 17, 208-2 2.

Stanier, R. Y. \& Smith, J. H. C. (1960). The chlorophylls of green bacteria. Biochimica et biophysica acta 4I, 478-484.

TrüPER, H. G. (1976). Higher taxa of the phototrophic bacteria: Chloroflexaceae fam. nov., a family for the gliding, filamentous, phototrophic ' green' bacteria. International Journal of Systematic Bacteriology 26, 74-75.

WAlter, M. R., BAUld, J. \& Brock, T. D. (1972). Siliceous algal and bacterial stromatolites in hot spring and geyser effluents of Yellowstone National Park. Science 178, 402-405. 